\title{
Photosynthetic capacity, nutrient status, and growth of maize (Zea mays L.) upon $\mathrm{MgSO}_{4}$ leaf-application
}

\author{
Mareike Jezek, Christoph-Martin Geilfus, Anne Bayer and Karl-Hermann Mühling*
}

Faculty of Agricultural and Nutritional Sciences, Institute of Plant Nutrition and Soil Science, Kiel University, Kiel, Germany

\section{Edited by:}

Paul Christiaan Struik, Wageningen University, Netherlands

Reviewed by:

Jyostna Devi Mura, North Carolina State University, USA

Tjeerdjan Stomph, Wageningen University, Netherlands

\section{*Correspondence:}

Karl-Hermann Mühling, Faculty of Agricultural and Nutritional Sciences, Institute of Plant Nutrition and Soil

Science, Kiel University,

Hermann-Rodewald-Straße 2,

24118 Kiel, Germany

e-mail:khmuehling@plantnutrition. uni-kiel.de

\begin{abstract}
The major plant nutrient magnesium (Mg) is involved in numerous physiological processes and its deficiency can severely reduce the yield and quality of crops. Since Mg availability in soil and uptake into the plant is often limited by unfavorable soil or climatic conditions, application of $\mathrm{Mg}$ onto leaves, the site with highest physiological $\mathrm{Mg}$ demand, might be a reasonable alternative fertilization strategy. This study aimed to investigate, if $\mathrm{MgSO}_{4}$ leaf-application in practically relevant amounts can efficiently alleviate the effects of $\mathrm{Mg}$ starvation in maize, namely reduced photosynthesis capacity, disturbed ion homeostasis and growth depression. Results clearly demonstrated that $\mathrm{Mg}$ deficiency could be mitigated by $\mathrm{MgSO}_{4}$ leaf-application as efficiently as by resupply of $\mathrm{MgSO}_{4}$ via the roots in vegetative maize plants. Significant increases in SPAD values and net rate of $\mathrm{CO}_{2}$-assimilation as well as enhanced shoot biomass have been achieved. Ion analysis furthermore revealed an improvement of the nutrient status of Mg-deficient plants with regard to $[\mathrm{Mg}],[\mathrm{K}]$, and $[\mathrm{Mn}]$ in distinct organs, thereby reducing the risk of Mn-toxicity at the rootside, which often occurs together with Mg deficiency on acid soils. In conclusion, foliar fertilization with $\mathrm{Mg}$ proved to be an efficient strategy to adequately supply maize plants with $\mathrm{Mg}$ and might hence be of practical relevance to correct nutrient deficiencies during the growing season.
\end{abstract}

Keywords: foliar application, magnesium deficiency, photosynthesis, chlorophyll, cation interaction, Zea mays L.

\section{INTRODUCTION}

The macronutrient magnesium $(\mathrm{Mg})$ is involved in numerous physiological processes during plant growth and development, extending far beyond its well-known function as central atom of chlorophyll. $\mathrm{Mg}$ activates more than 300 enzymes, e.g., ribulose1,5-bisphosphate-carboxylase/oxygenase (RubisCO), glutamine synthetase or glutathione synthase, and therefore participates in the assimilation of carbon, nitrogen, and sulfur, respectively (Marschner, 2012). Furthermore, Mg-binding to ATP is essential for the plasma membrane $\mathrm{H}^{+}$-ATPases activity, having Mg-ATP as substrate (Balke and Hodges, 1975). Consequently, phloem loading and partitioning of photoassimilates from source to sink organs depends on Mg availability (Cakmak etal., 1994a,b). Protein biosynthesis cannot take place without $\mathrm{Mg}$, since it connects the subunits of ribosomes (Maathuis, 2009).

Being aware of its impact on plant metabolism, it seems astonishing that $\mathrm{Mg}$ has received little attention in agricultural research in the last decades although its deficiency can cause severe reductions in yield and quality of crops (Gransee and Führs, 2013; Neuhaus et al., 2014). Genetic responses to Mg starvation and restoration have been analyzed in the model species Arabidopsis thaliana (Hermans et al., 2010a,b), but Cakmak and Yazici (2010) called Mg 'a forgotten element in crop production.' The authors consider the deficiency of this nutrient to be a growing problem and limiting factor especially in intensive production systems, consequently also striking human and animal health (Cakmak, 2013).
Magnesium deficiency in plants may occur on soils even under high $\mathrm{Mg}$ content of parent soil material. Owing to its unique chemical properties, it is only weakly bound to negatively charged soil particles and is therefore easily replaced by other cations and consequently leached (Maathuis, 2009; Gransee and Führs, 2013). Hence, calcareous soils, acidic soil with excess of protons $\left(\mathrm{H}^{+}\right)$, aluminium ( $\mathrm{Al}$ ) and manganese $(\mathrm{Mn})$, and saline soils with high amounts of sodium $(\mathrm{Na})$ are all prone to $\mathrm{Mg}$ deficiency (Mengel and Kirkby, 2001; Gransee and Führs, 2013). Also, elevated rates of NPK-fertilization in high-production systems harbor the risk of $\mathrm{Mg}$ deficiency, because strong reciprocal interactions regarding uptake exist among potassium $(\mathrm{K})$ and $\mathrm{Mg}$ (Guiet-Bara et al., 2007; Cai et al., 2012). Mg is delivered to the rhizosphere mainly by mass flow (Lynch and St. Clair, 2004) and thus dry soil and low transpiration rates impair Mg uptake additionally. Taking together all these factors that limit Mg availability in soils, an application of $\mathrm{Mg}$ directly on leaves where the physiologically $\mathrm{Mg}$ demand is highest might be more advantageous than a Mg fertilization of soils with restricted potential of $\mathrm{Mg}$ uptake by plant roots. Moreover, such a foliar application allows a precise timing of Mg supply temporally and spatially to satisfy the varying demands of distinct plant organs at different growth stages. Positive effects of Mg foliar fertilization on plant growth have already been described for some crops for example soybean and faba bean (Vrataric et al., 2006; Neuhaus et al., 2013, 2014) but plant responses to foliar fertilizers differ immensely among plant species due to diverse leaf surface properties such as trichomes, cuticula chemistry and cell wall composition (Fernández et al., 2013) and can thus not be generalized. 
Although it is the most extensively cultivated cereal crop worldwide (Pechanova et al., 2013), the response of maize (Zea mays L.) to $\mathrm{Mg}$ fertilization is less recognized than for other cereals (Grzebisz, 2013) especially regarding foliar fertilization. To cover the growing worldwide demands, ranging from feed for humans and animals to biofuel production and energy generation, maize cultivation has expanded immensely in the last decade also on marginal soils, which harbor the risk of $\mathrm{Mg}$ deficiency (Oikeh et al., 2003).

The aim of this study was to examine whether leaf-application of $\mathrm{MgSO}_{4}$ in practically relevant amounts is as efficient as resupply of $\mathrm{Mg}$ via the roots in alleviating adverse effects of $\mathrm{Mg}$ deficiency in maize, namely low photosynthesis rate, disturbed ionic homeostasis and biomass reduction. A hydroponic cultivation experiment with four distinct experimental groups was conducted in the greenhouse and photosynthesis rate, SPAD values, biomass as well as $[\mathrm{Mg}],[\mathrm{K}]$, and $[\mathrm{Mn}]$ in different organs were determined.

\section{MATERIALS AND METHODS}

\section{PLANT GROWTH CONDITIONS}

Maize (Zea mays L. cv. Susann, Nordsaat Saatzucht, Langenstein, Germany) plants were grown hydroponically in the greenhouse at $20-25^{\circ} \mathrm{C}$ and $30-50 \%$ relative humidity from June-July under natural light regime. Seeds were soaked in $2 \mathrm{mM}$ aerated $\mathrm{CaSO}_{4}$ solution for 2 days and germinated in sterile quartz sand, which was kept moistened with $2 \mathrm{mM} \mathrm{CaSO}_{4}$. Seven-days-old seedlings were transferred into $9 \mathrm{~L}$ plastic vessels (four plants per vessel) with $25 \%$ strength nutrient solution (NS), which was raised stepwise to $100 \%$ strength within 4 days. The full-strength NS had the following composition: $1.3 \mathrm{mM} \mathrm{Ca}\left(\mathrm{NO}_{3}\right)_{2}, 0.7 \mathrm{mM} \mathrm{NH}_{4} \mathrm{NO}_{3}$, $2.0 \mathrm{mM} \mathrm{CaCl}_{2}, 1.0 \mathrm{mM} \mathrm{K}_{2} \mathrm{SO}_{4}, 0.2 \mathrm{mM} \mathrm{KH}_{2} \mathrm{PO}_{4}, 200 \mu \mathrm{M} \mathrm{Fe}-$

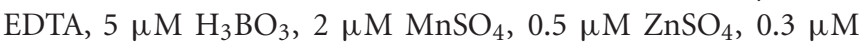
$\mathrm{CuSO}_{4}, 0.01 \mu \mathrm{M}\left(\mathrm{NH}_{4}\right)_{2} \mathrm{Mo}_{7} \mathrm{O}_{24}$, and it was exchanged weekly. Four different experimental groups with distinct $\mathrm{Mg}$ treatments were cultivated in four independent biological replicates, including positive control with sufficient $\mathrm{Mg}$ and negative control with severe Mg deficiency (Figure 1). Vessels were arranged fully randomized. Plants of the positive control group were supplied with $0.5 \mathrm{mM}$ $\mathrm{MgSO}_{4}$ in the NS, whereas the other three groups grew under $0.02 \mathrm{mM} \mathrm{MgSO}_{4}$ for 9 days to ensure proper seedling development. In order to induce clear $\mathrm{Mg}$ deficiency symptoms, $[\mathrm{Mg}]$ was further reduced to $0.01 \mathrm{mM} \mathrm{MgSO}_{4}$ thereafter. After a growing period of 5 weeks, the NS [Mg] of one of the three deficiency groups was raised to $0.5 \mathrm{mM} \mathrm{MgSO}_{4}$. Another deficiency group was fertilized with $\mathrm{Mg}$ over the leaves while still growing in $0.01 \mathrm{mM} \mathrm{MgSO}_{4} \mathrm{NS}$. This leaf-application treatment was conducted four times within 10 days by brushing $200 \mathrm{mM} \mathrm{MgSO}_{4}$ on the whole plants, namely

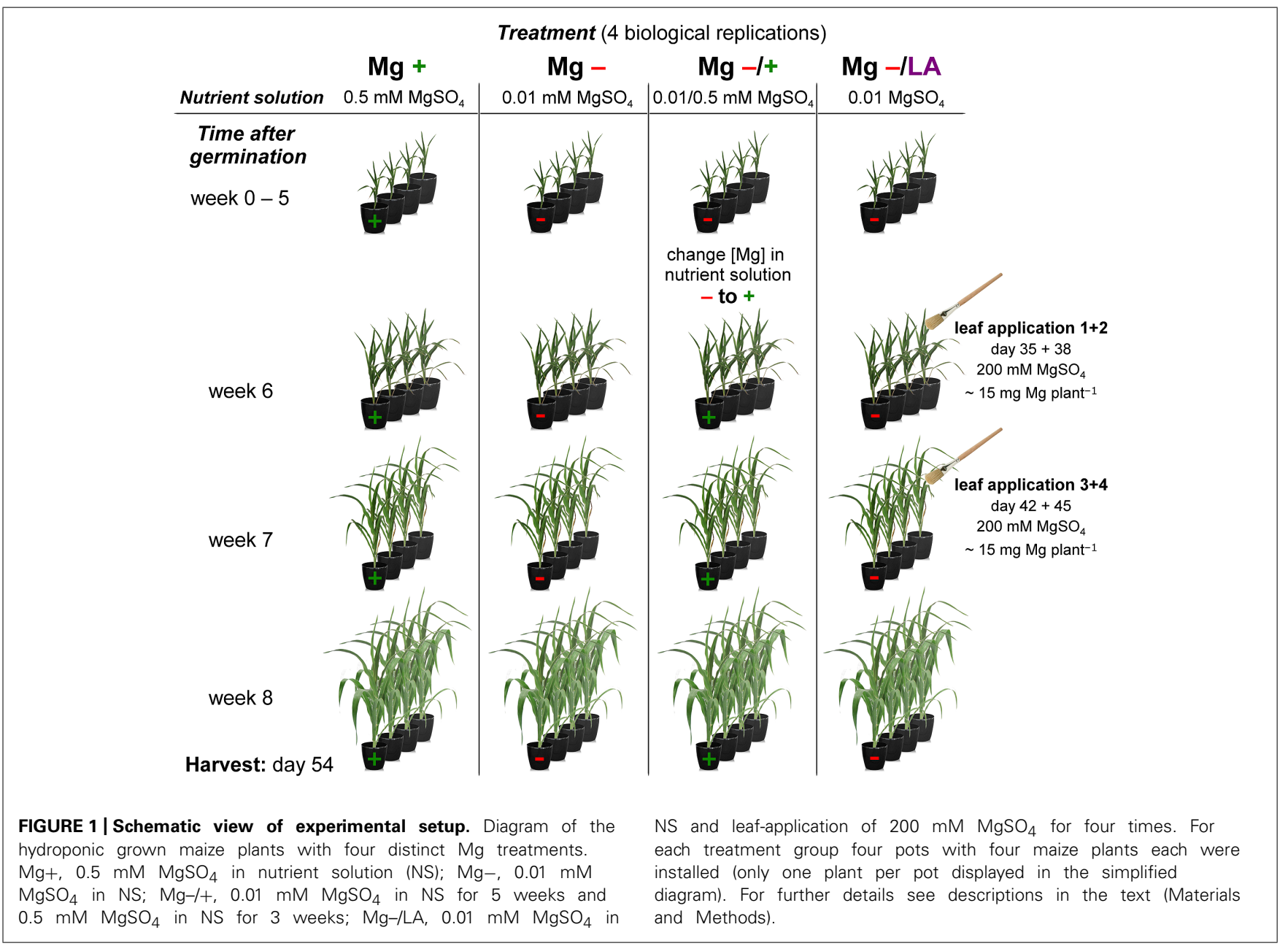


abaxial and adaxial leaf sides as well as the stems. By this special means the amount of $\mathrm{Mg}$ applied which directly reached the plants surface could exactly be quantified. Each plant received $60 \mathrm{mg} \mathrm{Mg}$ in total, which would correspond to an application rate of approximately $6 \mathrm{~kg} \mathrm{ha}^{-1}$ under field conditions. Leaf-application solution contained $0.1 \%$ Silwet as wetting agent and treatments took place in the morning to ensure opened stomata and to avoid leaf burnings by high irradiation. Plants were harvested after 54 days of growth.

\section{SPAD VALUES AND GAS EXCHANGE MEASUREMENTS}

Changes in chlorophyll concentration of the 6th leaf were measured non-destructively using a portable chlorophyll meter (SPAD-502, Minolta, Japan) starting at day 26 after germination until harvest. In addition, the ninth leaf was analyzed at harvest. Measurements were performed on two plants per vessel of each of the four biological replicates, four readings per leaf were taken and values were averaged.

Rate of photosynthetic activity was measured regularly starting with the onset of leaf-application on day 35 of the experiment by a portable gas exchange system (LI-6400, LI-COR Biosciences, Lincoln, NE, USA). Measurements were conducted between 10 am and $14 \mathrm{pm}$ on a central $6 \mathrm{~cm}^{2}$ leaf segment next to the midrib of the sixth leaf. Measurements were taken at two plants of two biological replicates per treatment and values were averaged. Incoming photosynthetic photon flux density provided by a red/blue LED light source (6400-02B, LI-COR Biosciences, Lincoln, NE, USA) amounted to $600 \mu \mathrm{mol} \mathrm{m}^{-2} \mathrm{~s}^{-1}$ and ambient $\mathrm{CO}_{2}$ concentration was adjusted to $400 \mu \mathrm{mol} \mathrm{mol}^{-1}$ by $\mathrm{CO}_{2}$ injection (6400-01, LI-COR Biosciences, Lincoln, NE, USA) as described in detail by Geilfus et al. (2011).

\section{ANALYSIS OF PLANT TISSUE}

Fresh weight (FW) of total shoot and several leaves (sixth to eight and youngest leaf) were determined by pooling all four plants per vessel and dividing the values by four.

For mineral analysis, plant tissue was dried at $60^{\circ} \mathrm{C}$, ground and $100 \mathrm{mg}$ were digested with $10 \mathrm{~mL}$ of $69 \% \mathrm{HNO}_{3}$ (ROTIPURAN Supra for ICP, 69\%) in a $1800 \mathrm{~W}$ microwave oven (MARS 6 Xpress; CEM, Matthews, MC, USA) with the following program: $2 \mathrm{~min}$ at $100^{\circ} \mathrm{C}, 1 \mathrm{~min}$ at $120^{\circ} \mathrm{C}, 20 \mathrm{~min}$ at $180^{\circ} \mathrm{C}, 20 \mathrm{~min}$ cooling time. Samples were diluted with distilled sterile water (18.2 M $\Omega$ $\mathrm{cm}$ conductivity) to $100 \mathrm{~mL}$ afterward and kept at $4^{\circ} \mathrm{C}$ until analysis. Concentrations of macro- and micronutrients were quantified using inductively coupled plasma-mass spectrometry (ICP-MS; Agilent Technologies 7700 Series, Böblingen, Germany). The analytical technique was standardized using NCS DC 73350, a certified reference material (leaves of poplar) from the China National Analysis Center for Ion and Steel (Beijing, China). Blank digestions were performed in the same way as for the samples. Every 20 samples, internal macro- and micronutrients standards, as well as reference material samples were analyzed as internal control.

\section{STATISTICS}

Data was statistically analyzed using $\mathrm{R}$ statistical package software version 3.0.1 (The $\mathrm{R}$ foundation for statistical computing, Vienna, Austria, 2013). Effects of treatments were tested using
Student's $t$-test in case of two experimental groups or with oneway ANOVA and following Bonferroni correction in case of four different groups.

\section{RESULTS \\ SPAD MEASUREMENTS}

The comparison between the Mg sufficient positive control plants (0.5 $\mathrm{mM} \mathrm{MgSO}_{4}$ in NS) and the $\mathrm{Mg}$ deficient negative control plants $\left(0.01 \mathrm{mM} \mathrm{MgSO}_{4}\right.$ in NS) revealed that $\mathrm{Mg}$ deficiency significantly influenced the chlorophyll concentrations in maize, as assessed by SPAD values (Figure 2). While SPAD values raised in leaves of well-nourished positive control plants until day 42 after germination and remained constant henceforth (black line), those of Mg deficient plants decreased until harvest (dotted line). With the onset of $\mathrm{Mg}$ resupply to deficient plants on day 35 after germination, SPAD values increased immediately in plants with root- and leaf-resupply to the same degree (light- and dark-gray dashed lines). Both treatments resulted in significantly elevated SPAD values compared to negative control plants after 2 days. At the end of the experiment, SPAD values in the sixth leaf of plants with $\mathrm{Mg}$ resupply did not reach the level of the positive control plants, regardless of whether $\mathrm{Mg}$ was given to the roots or the leaves. However, SPAD values in the ninth leaf were equal to the well-nourished positive control in both leaf-resupply and root-resupply treatment at harvest time (Table $\mathbf{1}$ ).

\section{PHOTOSYNTHESIS RATE AND TRANSPIRATION}

Gas exchange measurements revealed significant differences in net $\mathrm{CO}_{2}$-assimilation and transpiration rates of the 6 th leaf between $\mathrm{Mg}$ deficient negative control and well-nourished positive control plants 5 weeks after germination (Figures 3A,B). The 6th leaf of well-nourished control plants had stable assimilation rates of about $21 \mu \mathrm{mol} \mathrm{CO}_{2} \mathrm{~m}^{-2} \mathrm{~s}^{-1}$ during the course of the experiment (black line) whereas a continuous decrease was observed under $\mathrm{Mg}$ deficiency (dotted line) from $6.8 \mu \mathrm{mol} \mathrm{CO} \mathrm{m}^{-2} \mathrm{~s}^{-1}$ at day 37 to $2.0 \mathrm{CO}_{2} \mathrm{~m}^{-2} \mathrm{~s}^{-1}$ at day 51 (dotted line). Transpiration rates of the 6th leaf of $\mathrm{Mg}$ deficient plants were significantly reduced compared to well-nourished plants throughout the whole measuring period. Resupply of Mg to the NS (dark-gray dashed line) or via leaf-application (light-gray dashed line) significantly raised both net $\mathrm{CO}_{2}$-fixation and transpiration rate within 2 days in comparison to the negative control. Assimilation rates continued to increase until they reached the level of positive control plants 6 days after $\mathrm{Mg}$ resupply via the roots and after 9 days, if $\mathrm{MgSO}_{4}$ was applied onto leaves, respectively. The latter had been treated with $200 \mathrm{mM} \mathrm{MgSO} 4$ solution for three times by then, which amounts to $45 \mathrm{mg} \mathrm{Mg}$ per plant. Transpiration rates equaled those of positive control plants after 6 days in both treated groups.

\section{PLANT GROWTH}

Shoot FW of negative control plants was significantly reduced and amounted to $30.5 \mathrm{~g} \mathrm{shoot}^{-1}$ which accounted for $11.0 \%$ of adequately nourished positive control plants (Figure 4A). This reduction in FW of negative controls was also apparent in leaves number six, seven, eight, and in the youngest leaves (Figure 4B). $\mathrm{Mg}$ supply after 5 weeks of deficiency significantly raised shoot FW 


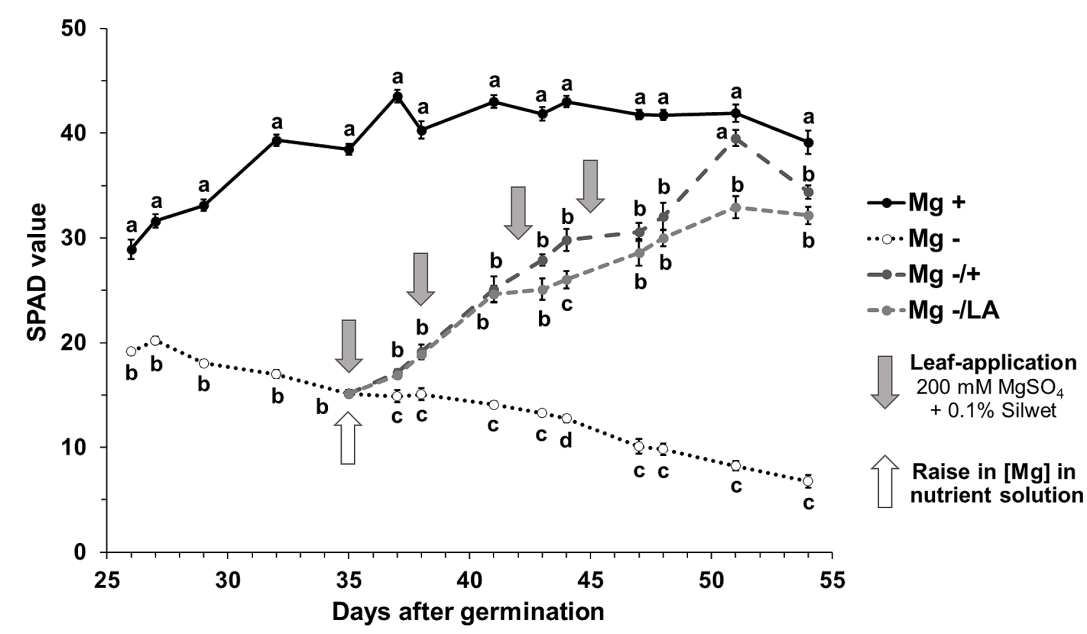

FIGURE 2 | Course of SPAD values of the sixth leaf over time. Relative chlorophyll concentration in the sixth leaf assessed by SPAD measurements. $\mathrm{Mg}+, 0.5 \mathrm{mM} \mathrm{MgSO}_{4}$ in NS; $\mathrm{Mg}-, 0.01 \mathrm{mM} \mathrm{MgSO}_{4}$ in NS; Mg-/+, $0.01 \mathrm{mM}$ $\mathrm{MgSO}_{4}$ in NS for 5 weeks and $0.5 \mathrm{mM} \mathrm{MgSO}_{4}$ in NS for 3 weeks; Mg-/LA, $0.01 \mathrm{mM} \mathrm{MgSO}_{4}$ in NS and leaf-application of $200 \mathrm{mM} \mathrm{MgSO}_{4}$ for four times. Measurements were made on two plants of each of the four biological replicates per treatment; four individual SPAD values per leaf were averaged. Mean \pm SE; arrows show date of leaf-application with $200 \mathrm{mM} \mathrm{MgSO}_{4}$; small letters indicate significant differences between treatments for an observation date (ANOVA with Bonferroni adjustment, $p \leq 0.05$ ).
Table 1 | SPAD values in the ninth leaf at day 54 after germination.

\begin{tabular}{llll}
\hline & Treatment & SPAD & SE \\
\hline $\mathrm{Mg}+$ & (Positive control) & $37.8^{\mathrm{a}}$ & 1.0 \\
$\mathrm{Mg}-$ & (Negative control) & $16.0^{\mathrm{b}}$ & 0.5 \\
$\mathrm{Mg}-I_{+}$ & (Root-resupply) & $37.2^{\mathrm{a}}$ & 0.8 \\
$\mathrm{Mg}-/ \mathrm{LA}$ & (Leaf-application) & $35.7^{\mathrm{a}}$ & 1.5 \\
\hline
\end{tabular}

$\mathrm{Mg}+, 0.5 \mathrm{mMMgSO}_{4}$ in nutrient solution (NS); $\mathrm{Mg}-, 0.01 \mathrm{mMMgSO}_{4}$ in $\mathrm{NS} ; \mathrm{Mg}-$ It, $0.01 \mathrm{mM} \mathrm{MgSO}_{4}$ in NS for 5 weeks and $0.5 \mathrm{mM} \mathrm{MgSO}_{4}$ in NS for 3 weeks, $\mathrm{Mg}-/ \mathrm{LA}, 0.01 \mathrm{mM} \mathrm{MgSO}_{4}$ in NS and leaf-application of $200 \mathrm{mM} \mathrm{MgSO}_{4}$ for four times. Measurements were made on two plants of each of the four biological replicates per treatment; four individual SPAD values per leaf were averaged. Mean $\pm S E ;$ small letters indicate significant differences between treatments (ANOVA with Bonferroni adjustment, $p \leq 0.05$ ).

to the same extent regardless of whether it was given to the NS or applied onto leaves (Figure 4A). Mean FW were $125.3 \mathrm{~g} \mathrm{shoot}^{-1}$ for root-resupply and $103.4 \mathrm{~g}$ shoot $^{-1}$ in plants with $\mathrm{MgSO}_{4}$ leafapplication. Resupply of $\mathrm{Mg}$ increased FW of the eighth leaf to the largest extent (Figure 4B). In comparison to Mg-deficient plants, no increase in FW was observed in leaf number six upon Mg resupply via leaves or the NS. Mg addition to the NS raised the FW of leaf number seven and the youngest leaf compared to the negative control plants. Upon $\mathrm{MgSO}_{4}$ leaf-application FW of these leaves were not significantly different from neither the negative control nor the plants with $\mathrm{Mg}$-resupply via the roots.

\section{Mg, K AND Mn CONCENTRATIONS IN DISTINCT PLANT ORGANS}

Positive control plants cultivated in NS with $0.5 \mathrm{mM} \mathrm{MgSO}_{4}$ showed [Mg] between $1.5 \mathrm{~g} \mathrm{Mg} \mathrm{kg}^{-1}$ dry weight (DW) in youngest and $2.7 \mathrm{~g} \mathrm{Mg} \mathrm{kg}^{-1} \mathrm{DW}$ in oldest investigated leaves; root tissue contained $2.7 \mathrm{~g} \mathrm{Mg} \mathrm{kg}^{-1} \mathrm{DW}$ (Figure 5A). Severe $\mathrm{Mg}$ starvation affected $[\mathrm{Mg}]$ significantly in the sixth leaf, in the youngest leaves and in root tissue. Addition of $0.5 \mathrm{mM} \mathrm{MgSO}_{4}$ to the NS after 5 weeks of $\mathrm{Mg}$ deficiency significantly raised $[\mathrm{Mg}]$ in all leaves and, predominantly, in the roots, which contained almost 70\% more $\mathrm{Mg}$ in comparison to positive control plants. Resupply of $\mathrm{Mg}$ through leaf application resulted in a prominent increase of $[\mathrm{Mg}]$ in basal leaves. Leaves number six to eight contained 3.8 up to $12.6 \mathrm{~g} \mathrm{Mg} \mathrm{kg}^{-1} \mathrm{DW}$, increasing with decreasing leaf number. Youngest leaves and roots, in contrast, were not affected and did not have a significantly higher $[\mathrm{Mg}]$ than $\mathrm{Mg}$ deficient negative control plants.

The dose and method of $\mathrm{Mg}$ nutrition also influenced $[\mathrm{K}]$ in the plant tissues (Figure 5B). Growth in NS with $0.01 \mathrm{mM} \mathrm{MgSO}_{4}$ elevated $[\mathrm{K}]$ significantly in leaves number six to eight, but not in youngest leaves and roots. With 46.9 to $65.0 \mathrm{~g} \mathrm{~K} \mathrm{~kg}^{-1} \mathrm{DW},[\mathrm{K}]$ in basal leaves of negative control plants were up to 1.8 times as high as in positive control plants, which contained 32.3 to $38.7 \mathrm{~g} \mathrm{~K} \mathrm{~kg}^{-1}$ DW. Re-nutrition with $\mathrm{MgSO}_{4}$ via roots significantly reduced [K] in whole shoots and roots to levels of control plants, whereas [K] in the eighth leaf and roots remained elevated, if $\mathrm{MgSO}_{4}$ leafapplication was performed.

Magnesium deficient negative control plants showed high [Mn] not only in leaves, but predominantly in roots. With $162.8 \mathrm{mg}$ $\mathrm{Mn} \mathrm{kg}^{-1}$ DW they contained 13.4 times more Mn than positive control plants (12.1 $\mathrm{mg} \mathrm{Mn} \mathrm{kg}^{-1} \mathrm{DW}$; Figure 5C). Increasing the $\mathrm{MgSO}_{4}$ concentration in the NS led to a significant decrease of [Mn] in all examined plant parts to levels of the positive control group. Leaf-application of $\mathrm{MgSO}_{4}$, by contrast, only reduced [Mn] significantly in youngest leaves and roots, whereas they remained as high as in negative control plants in the older leaves.

\section{DISCUSSION}

Magnesium deficiency is considered to be a growing problem throughout agriculture and it occurs on diverse soil types (Mengel and Kirkby, 2001). Since Mg availability in soil and uptake into 


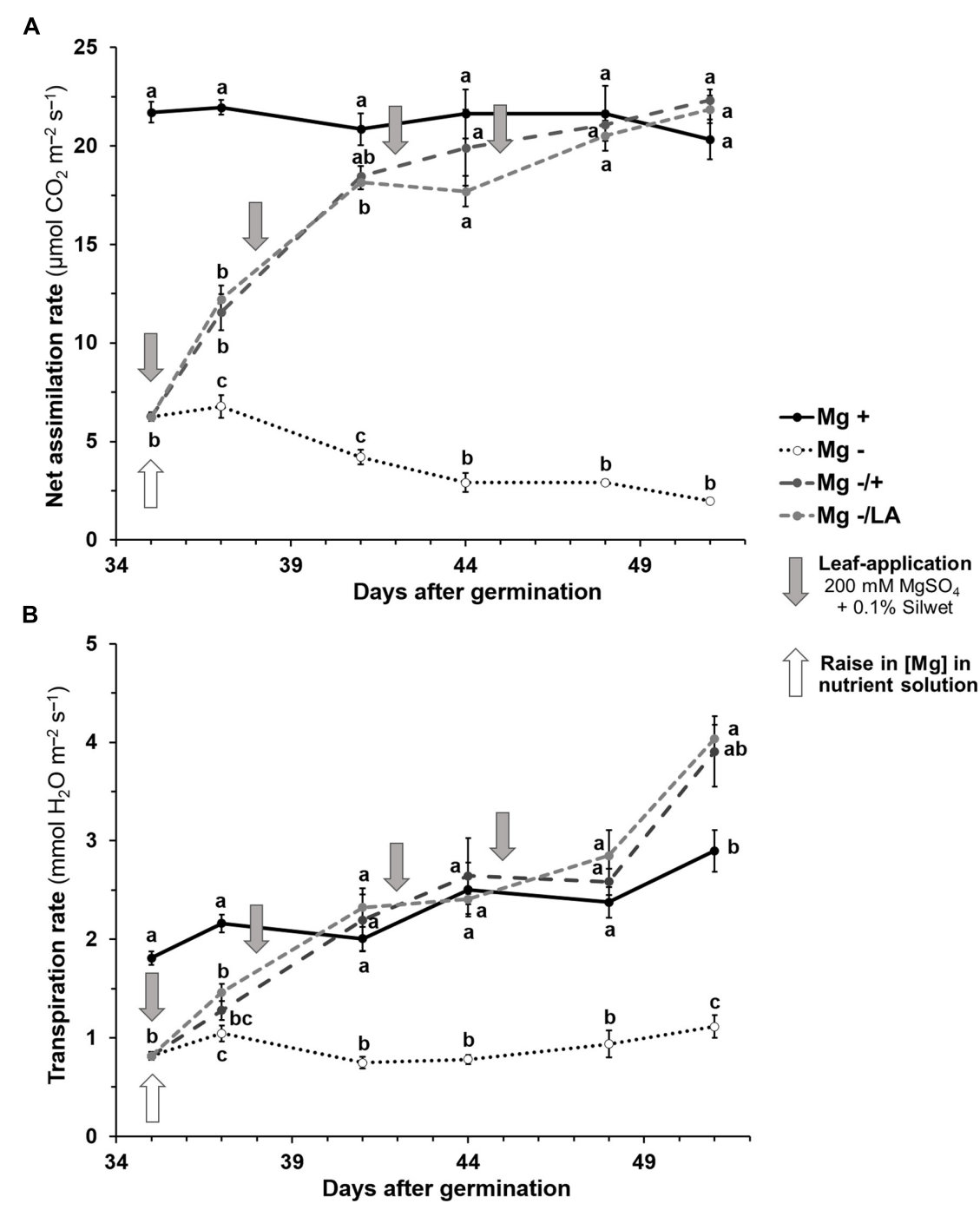

FIGURE 3 | Course of gas exchange measurements of the sixth leaf over time. (A) Net $\mathrm{CO}_{2}$ assimilation rate $\left(\mu \mathrm{mol} \mathrm{CO}_{2} \mathrm{~m}^{-2} \mathrm{~s}^{-1}\right.$ ) of the sixth leaf. (B) Transpiration rate $\left(\mathrm{mmol} \mathrm{H} \mathrm{H} \mathrm{m}^{-2} \mathrm{~s}^{-1}\right)$ of the sixth leaf. $\mathrm{Mg}+, 0.5 \mathrm{mM} \mathrm{MgSO}_{4}$ in nutrient solution (NS); Mg-, $0.01 \mathrm{mM} \mathrm{MgSO}_{4}$ in NS; Mg-/+, $0.01 \mathrm{mM} \mathrm{MgSO}_{4}$ in NS for 5 weeks and $0.5 \mathrm{mM} \mathrm{MgSO}_{4}$ in NS for 3 weeks; $\mathrm{Mg}-/ \mathrm{LA}, 0.01 \mathrm{mM} \mathrm{MgSO}_{4}$ in NS and leaf-application of $200 \mathrm{mM} \mathrm{MgSO}_{4}$ for four times. Measurements were made on two plants of two biological replicates per treatment. Mean $\pm \mathrm{SE}$; arrows show date of leaf-application with $200 \mathrm{mM} \mathrm{MgSO}$; small letters indicate significant differences between treatments for an observation date (ANOVA with Bonferroni adjustment, $p \leq 0.05)$. the plant often is limited foliar fertilization instead of $\mathrm{Mg}$ addition to the soil seems reasonable for meeting the crop's demands. Therefore, it was questioned, if foliarly applied $\mathrm{Mg}$ could alleviate $\mathrm{Mg}$ deficiency syndromes in vegetative maize plants as fast and efficient as a resupply via the roots. The amount of foliarly applied $\mathrm{Mg}$ was exactly quantified and amounted to $60 \mathrm{mg} \mathrm{Mg}$ per plant in total, which corresponds to a practically relevant application rate of approximately $6 \mathrm{~kg} \mathrm{Mg} \mathrm{ha}^{-1}$. Several physiological reactions of maize plants under severe $\mathrm{Mg}$ starvation and subsequent resupply of $\mathrm{Mg}$ via leaf- or root-fertilization were investigated by hydroponic cultivation.

Negative control plants grown in $0.01 \mathrm{mM} \mathrm{MgSO}_{4}$ showed strong reductions in photosynthesis and biomass, which is in accordance with several studies on other crops (Gerendás and
Führs, 2013; Neuhaus et al., 2014). The negative effects on such yield-relevant physiological processes once again illustrate the importance of $\mathrm{Mg}$ as a plant macronutrient and underline the need for developing adequate $\mathrm{Mg}$ application strategies to ensure high plant productivity.

\section{LEAF-APPLICATION OF MgSO4 RAPIDLY INCREASES [Mg] IN Mg DEFICIENT MAIZE}

Bergmann (1983) states $[\mathrm{Mg}]$ in fully expanded maize leaves to range from 2.5 to $6.0 \mathrm{~g} \mathrm{~kg}^{-1} \mathrm{DW}$. According to that threshold, positive control plants were sufficiently supplied with $\mathrm{Mg}$ whereas $\mathrm{Mg}$ deficient negative controls were growing under severe malnutrition (Figure 6A). Increasing $[\mathrm{Mg}]$ in the NS after 5 weeks of $\mathrm{Mg}$ restriction led to elevated $[\mathrm{Mg}]$ especially in newly developed 

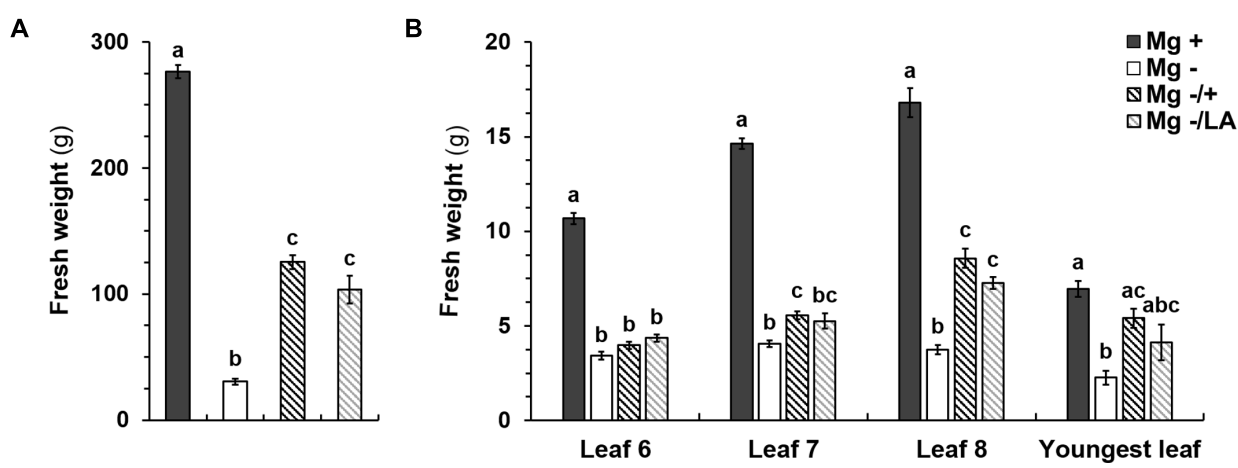

FIGURE 4 | Fresh weights (FWs) of shoots and single leaves. (A) FW (g) of shoots and of (B) leaves number six, seven, eight, and youngest leaves at harvest (54 days after germination). $\mathrm{Mg}+, 0.5 \mathrm{mM} \mathrm{MgSO}_{4}$ in NS; Mg-, $0.01 \mathrm{mM} \mathrm{MgSO}_{4}$ in NS; Mg-/+, $0.01 \mathrm{mM} \mathrm{MgSO}_{4}$ in NS for 5 weeks and
$0.5 \mathrm{mM} \mathrm{MgSO}_{4}$ in NS for 3 weeks; Mg-/LA, $0.01 \mathrm{mM} \mathrm{MgSO}_{4}$ in NS and leaf-application of $200 \mathrm{mM} \mathrm{MgSO}_{4}$ for four times; mean ( $n=4$ biological replicates) $\pm \mathrm{SE}$; small letters indicate significant differences between treatments (ANOVA with Bonferroni adjustment, $p \leq 0.05$ ). leaves and to minor extent in those, which had already been built under deficiency conditions (Figure 5A). Furthermore, $[\mathrm{Mg}]$ in roots markedly increased, which might indicate elevated uptake after a time of nutrient deprivation. This would be in agreement

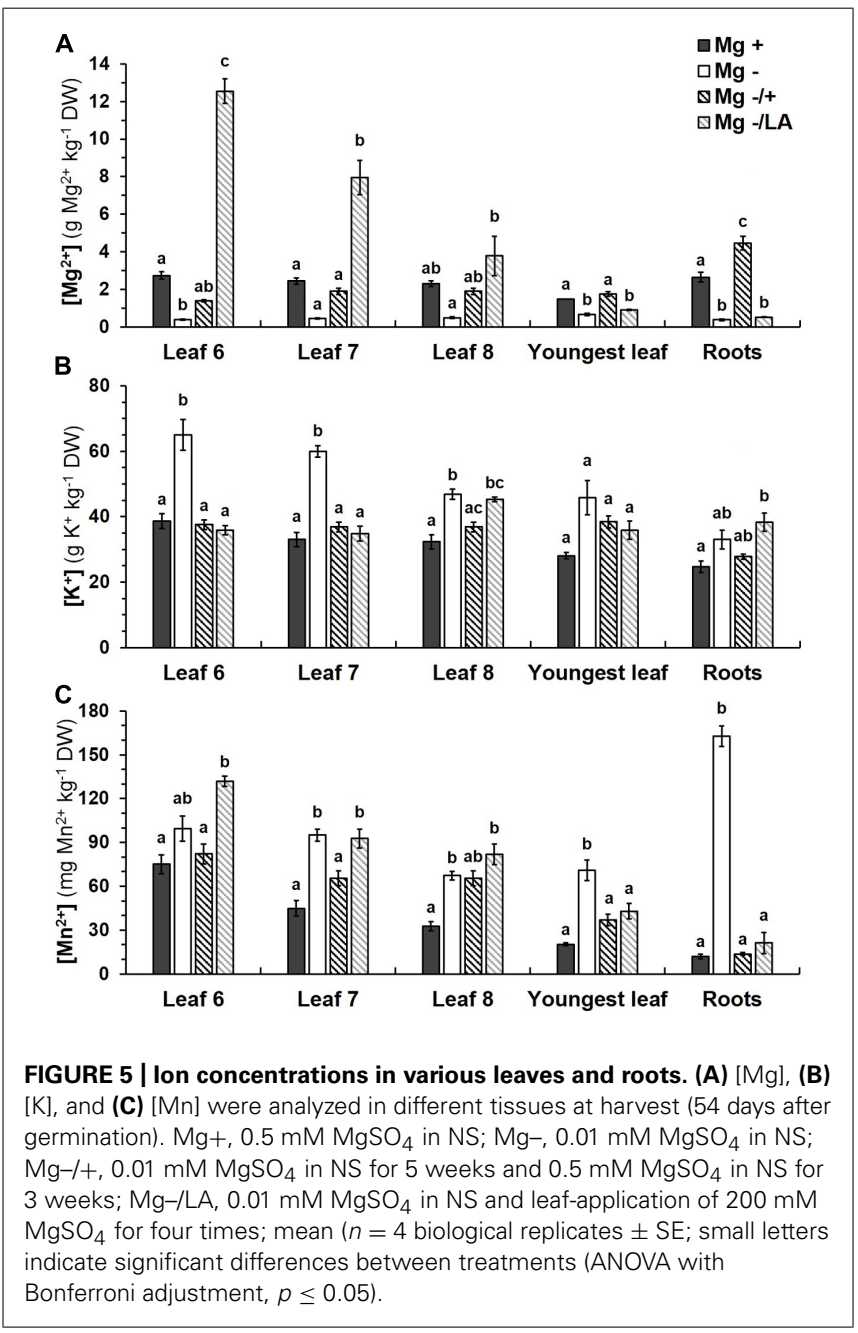

with results from Cai etal. (2012), who found a putative Mg transporter gene to be up-regulated under $\mathrm{Mg}$ deficiency in rice. Nevertheless, our data do not reveal $\mathrm{Mg}$ uptake into the symplast of root cells since cation concentrations of the whole tissue has been analyzed. Leaf-application of $200 \mathrm{mM} \mathrm{MgSO}_{4}$ remarkably increased $[\mathrm{Mg}]$ in leaves that had directly been treated by foliar application. Declining $[\mathrm{Mg}]$ in the upper leaves are attributable to the number of foliar application treatments. The sixth leaf was treated four times with $\mathrm{MgSO}_{4}$ solution whereas leaf number eight only received one application. It is surprising that $\mathrm{MgSO}_{4}$ leaf-application did not affect $[\mathrm{Mg}]$ in roots and youngest leaves, which did not receive $\mathrm{MgSO}_{4}$ application, since $\mathrm{Mg}$ is known to be a highly phloem-mobile cation, which can be translocated within the plant to sites of high nutrient demand (Steucek and Koontz, 1970; White and Broadley, 2009). However, the Mg demand of roots is relatively low, given its primary role in chloroplasts (Maathuis, 2009) and [Mg] in youngest leaves obviously were high enough to significantly increase chlorophyll concentrations in youngest leaves (Table 1), as SPAD values were not different from well-nourished control plants at harvest.

\section{MAGNESIUM RESUPPLY VIA LEAVES RAPIDLY ENHANCES PHOTOSYNTHETIC PARAMETERS IN Mg DEFICIENT MAIZE}

Chlorophyll concentrations estimated by SPAD measurements were markedly reduced under $\mathrm{Mg}$ deficiency (Figure 2, dotted line) and leaves showed deficiency symptoms being typical in cereals like interveinal yellowing, chlorosis, and necrosis (Figures 6B,C). Mg resupply elevated SPAD values significantly already within 2 days and application of $200 \mathrm{mM} \mathrm{MgSO}_{4}$ to maize leaves turned out to be as efficient in raising SPAD values as addition of $0.5 \mathrm{mM} \mathrm{MgSO}_{4}$ to the roots (Figure 2, dark-gray and light-gray dashed lines, respectively). Even one single leaf application treatment and hence $15 \mathrm{mg} \mathrm{Mg}$ per plant was sufficient for triggering significant effects. The efficient uptake of $\mathrm{MgSO}_{4}$ solution into maize leaves can be ascribed to their amphistomatical anatomy and their wettability at both leaf sides (Urrego-Pereira et al., 2013). Raise in chlorophyll concentration by $\mathrm{Mg}$ foliar-application has also been shown for faba bean, oregano, and soybean before (Dordas, 2009; Teklic et al., 2009; Neuhaus et al., 2013). Mg not only serves as central atom of 


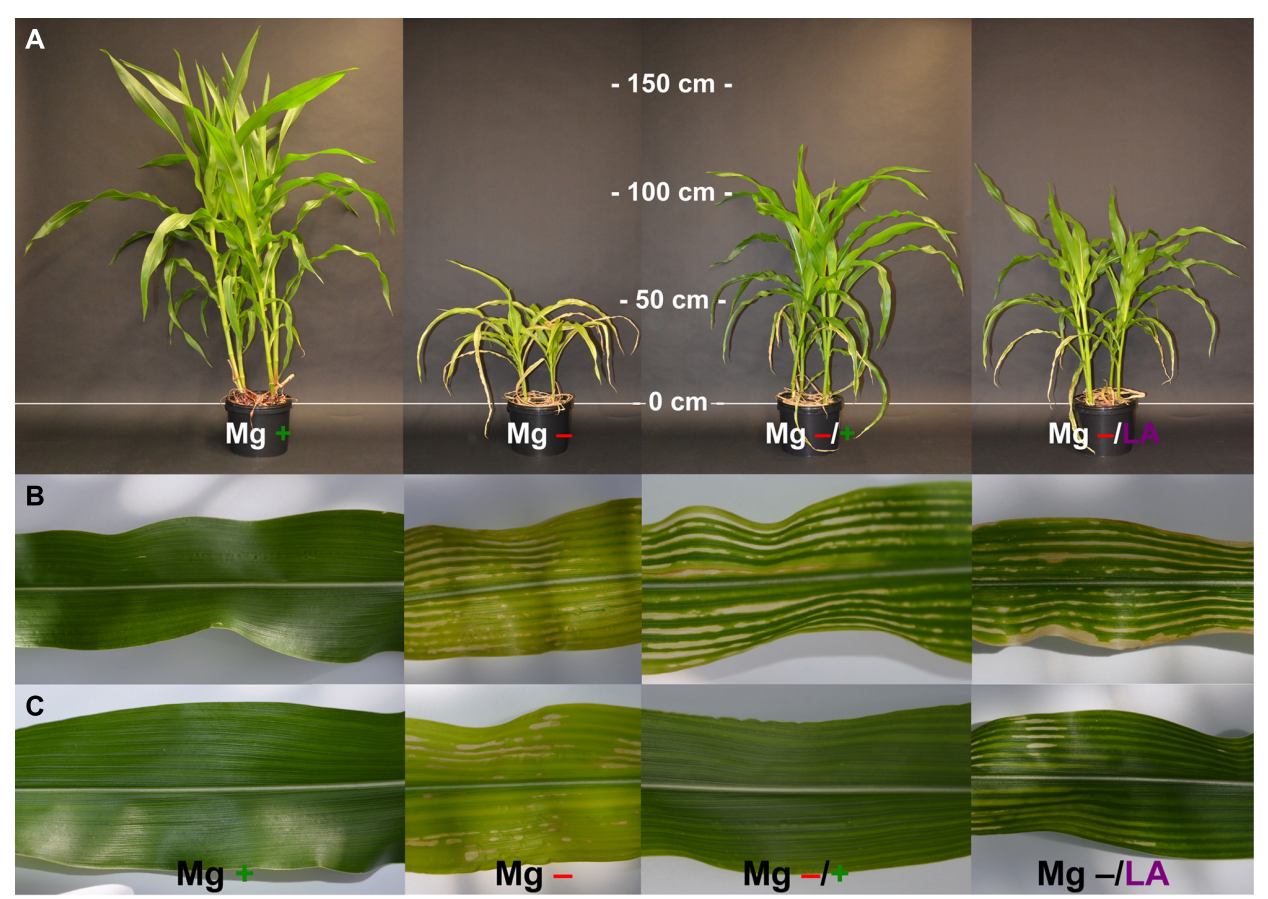

FIGURE 6 | Visual symptoms of Mg deficiency and effects of $\mathbf{M g}$ resupply. (A) Representative plants at harvest time (54 days after germination); (B,C) representative leaves of the sixth and seventh leaf respectively at day 44 after germination; plants with $\mathrm{MgSO}_{4}$ leaf-application had received three of four application-treatments by then. $\mathrm{Mg}+, 0.5 \mathrm{mM}$ $\mathrm{MgSO}_{4}$ in NS; Mg-, $0.01 \mathrm{mM} \mathrm{MgSO}_{4}$ in NS; Mg-/+, $0.01 \mathrm{mM} \mathrm{MgSO}_{4}$ in NS for 5 weeks and $0.5 \mathrm{mM} \mathrm{MgSO}_{4}$ in NS for 3 weeks; Mg-/LA, $0.01 \mathrm{mM}$ $\mathrm{MgSO}_{4}$ in NS and leaf-application of $200 \mathrm{mM} \mathrm{MgSO}_{4}$ for four times. chlorophyll molecules but is also necessary in chlorophyll biosynthesis, activating $\mathrm{Mg}$-chelatase, a complex enzyme which catalyzes the insertion of $\mathrm{Mg}$ into a chlorophyll precursor molecule (Reid and Hunter, 2004; Masuda, 2008). The high biological relevance of $\mathrm{Mg}$ for chlorophyll production hence explains the pronounced re-greening of all leaves already within a few days after $\mathrm{Mg}$ resupply (Figures 6B,C). Not only leaves that were directly treated with $\mathrm{MgSO}_{4}$ showed higher SPAD values compared to Mg-deficient control plants, but the effects of the leaf-application also became visible in the youngest, untreated leaves, where SPAD values were not significantly different from control plants or plants with root resupply at harvest time (Table 1 ). This suggests the uptake of the applied $\mathrm{Mg}$ into the cytosol and is furthermore indicative for the systemic effect of $\mathrm{MgSO}_{4}$ leaf-application in distant, untreated plant parts.

Increasing chlorophyll level assessed by SPAD measurements were certainly one reason why $\mathrm{CO}_{2}$-assimilation in the re-supplied treatments equaled to the level of the positive control plants after $\mathrm{Mg}$ had been restored via leaves or roots (Figure 3A). Similar to the SPAD values, the net $\mathrm{CO}_{2}$-fixation rate responded rapidly to $\mathrm{Mg}$ addition. Besides being the central atom of chlorophyll, $\mathrm{Mg}$ is furthermore involved in several other processes related to photophosphorylation and $\mathrm{CO}_{2}$-fixation (Lin and Nobel, 1971; Verbruggen and Hermans, 2013). For instance, Mg acts in charge balancing during the establishment of the proton motive force and activates several enzymes involved in photosynthesis, including RubisCO (Marschner, 2012). Also the transpiration rate rose upon $\mathrm{Mg}$ addition (Figure 3B), as was earlier observed in rice plants under Mg deficiency (Kobayashi et al., 2012). According to the authors this might be caused by a relationship between the ABA signaling network and $\mathrm{Mg}$ deficiency. The results show that the adverse effects of $\mathrm{Mg}$ deficiency on plant metabolism can be amended by $\mathrm{Mg}$ leaf-application as efficiently as by root resupply in maize plants, since no considerable differences between both treatments were detected.

Magnesium deficient maize plants were sufficiently supplied with sulfur through the NS ( $1 \mathrm{mM}$ sulfur) and showed no symptoms of sulfur deficiency throughout the whole growth period (Figures 6B,C). Hence, the described effects of $\mathrm{MgSO}_{4}$ leafapplication on physiological processes can be attributed to the influence of $\mathrm{Mg}$. Not only the added $\mathrm{Mg}$ directly improved photosynthetic processes through its participation in chlorophyll formation and enzyme activation, but a contribution of secondary effects is likely. To these belong for example, the restoration of ionic homeostasis especially regarding $[\mathrm{Mn}]$ in leaves because Mn stress was found to negatively impact the abundance of chloroplastic proteins important for $\mathrm{CO}_{2}$ fixation (Führs et al., 2008; Millaleo et al., 2013).

\section{MAGNESIUM FOLIAR APPLICATION DECREASES THE RELATIVE UPTAKE OF OTHER NUTRIENTS AT THE ROOTSIDE}

Ion analysis revealed that the $\mathrm{Mg}$ resupply not only affects $[\mathrm{Mg}]$ but also other cations such as $\mathrm{K}$ and $\mathrm{Mn}$ (Figures 5B,C). It has frequently been observed that variations in one nutrient is compensated by changing uptake of other cations instead (Morgan and Jackson, 1976; Mengel and Kirkby, 2001). Cations are in 
competition for apoplastic binding sites, e.g., negatively charged pectins, as well as for further uptake for example through nonselective cation channels (NSCC), which can be passed by both monovalent and divalent cations (Shabala and Hariadi, 2005). Hence, reciprocal effects among cations with respect to uptake into and distribution within the plant exist and antagonistic interactions of $\mathrm{Mg}$, $\mathrm{Ca}$, and $\mathrm{K}$ have been demonstrated for example in onion (Kleiber et al., 2012). Interestingly, amelioration of $\mathrm{Mg}$ deficiency by root- or leaf-application reduced $[\mathrm{K}]$ and $[\mathrm{Mn}]$ in distinct plant tissues to a varying extent.

\section{ELEVATED [K] UNDER Mg DEFICIENCY ARE DECREASED BY LEAF-APPLICATION OF Mg IN MAIZE SHOOTS}

Potassium concentrations, normally ranging from 30 to $45 \mathrm{~g}$ $\mathrm{kg}^{-1}$ DW in maize leaves (Bergmann, 1983), were found to be unusually high in $\mathrm{Mg}$ deficient plants, especially in older leaves (Figure 5B). These results seem plausible since $\mathrm{K}$ is a strong competitor for other cations due to its efficient uptake systems (Mengel and Kirkby, 2001) and are in accordance with results from Cai et al. (2012), who measured much higher K concentrations in rice shoots under $\mathrm{Mg}$ starvation and a moderate up-regulation of the expression of a high affinity $\mathrm{K}$ transporter gene. Such a hyperaccumulation of $\mathrm{K}$ with a subsequent growth-reduction has also been shown for plants, which were genetically restricted in their ability to store $\mathrm{Mg}$ in the vacuole (Gilliham et al., 2011). Elevated [K] under Mg deficiency might not only be explained by increased relative uptake, but also decreased export out of leaves into physiological sinks, since this process depends on ATPase activity and is known to be disturbed under Mg deficiency (Cakmak et al., 1994a,b).

Potassium concentrations decreased to the level of control plants upon resupply of $\mathrm{Mg}$ to the NS both in shoots and roots of maize, illustrating again the competitive interaction between these cations. Decreased K flux through NSCC with increasing $[\mathrm{Mg}]$ has also been detected in broad bean (Shabala and Hariadi, 2005). In contrast to $\mathrm{Mg}$ resupply via roots, $[\mathrm{K}]$ remained high in roots, if $\mathrm{MgSO}_{4}$ was foliarly applied to $\mathrm{Mg}$ deficient plants. This would be expected due to absence of $\mathrm{Mg}$ as a competitor in uptake at the rootside and the low $[\mathrm{Mg}]$ in the root tissue (Figure 5A). Nevertheless foliar treatment successfully lowered $[\mathrm{K}]$ in most investigated leaves significantly, not only in expanding tissue but also in mature leaves which have been built under deficient conditions.

\section{LEAF-APPLICATION OF $\mathrm{MgSO}_{4}$ REDUCES HIGH Mn CONCENTRATIONS IN Mg DEFICIENT MAIZE ROOTS}

Manganese is an essential micronutrient for plants and a major rival for $\mathrm{Mg}$ respecting uptake and transport due to their similar ionic radius and biochemical properties (Marschner, 2012). It occurs in different oxidation states and therefore plays a prominent role in redox processes, but can easily become phytotoxic if taken up in excess, which appears for example on soil with low $\mathrm{pH}$ or high redox potential (Kopittke et al., 2013). Effects of the competitive relationship between $\mathrm{Mg}$ and $\mathrm{Mn}$ vary between plant species, type of cultivation and nutrient concentrations in the medium. For example, elevated [Mn] in leaves of $\mathrm{Mg}$ deficient potato plants and wheat were measured (Cao and Tibbitts, 1992; Chatterjee et al., 1994), whereas the competitive effect of $\mathrm{Mg}$ on the uptake of Mn was low in rapeseed (Brassica napus) and hardly existed in lucerne (Medicago sativa; Löhnis, 1960).

Maize grown under Mg deficiency showed high [Mn] not only in leaves but especially in roots (Figure 5C). This might partially be caused by the absence of $\mathrm{Mg}$ as a competitor and subsequently increased Mn uptake at the rootside. However, a dilution effect caused by impaired root growth under Mg deficiency, which has been observed in bean plants for example (Cakmak et al., 1994b), might have contributed to markedly increased $[\mathrm{Mn}]$ in root tissue. In fact, the total amounts of accumulated Mn were the same for $\mathrm{Mg}$ deficient and well-supplied control plants (data not shown). $\mathrm{Mn}$ is commonly known to be easily transported from roots to above-ground plant organs (Horst, 1983), but excess accumulation of $\mathrm{Mn}$ in roots has been observed in cultivars of grape (Mou et al., 2011) and certain maize varieties (Stoyanova et al., 2009). Since $\mathrm{Mn}$ is easily transported from roots to the shoot in the xylem (Page and Feller, 2005), strong depression of transpiration under $\mathrm{Mg}$ deficiency (Figure 3B) might have further added the high [Mn] in roots. Impaired nutrient transport activities upon $\mathrm{Mg}$ deficiency have also been found in rice and have been explained by reduced transpiration (Kobayashi et al., 2012). Mn concentrations in roots of $\mathrm{Mg}$ deficient plants had almost reached toxic levels. The normal range of [Mn] is stated to be 40 to $150 \mathrm{mg}$ Mn kg-1 DW in maize shoots (Bergmann, 1983) and the critical toxicity concentration amounts to approximately $200 \mathrm{mg} \mathrm{Mn}$ $\mathrm{kg}^{-1}$ DW (Marschner, 2012), but clear differences in Mn tolerance exist among maize varieties (Stoyanova et al., 2009). Thus maize grown under severe $\mathrm{Mg}$ deficiency might already have experienced Mn toxicity at the rootside, being accountable for the observed shedding of fine roots during the experiment (data not shown). Such a loss of roots and reduced root growth in connection with increased [Mn] in root tissue has also been found in grape (Vitis vinifera) and was explained partially by oxidative stress leading to cellular damage (Mou et al., 2011). The phenomenon of root abscission due to oxidative stress has also been described for plants growing under heavy metal stress (Razinger et al., 2008; Xing et al., 2010).

Magnesium resupply to the NS successfully lowered $[\mathrm{Mn}]$ in both leaves and roots to the level of control plants, whereas $\mathrm{Mg}$ leaf-application reduced [Mn] only in youngest leaves and roots (Figure 5C). Reduction of [Mn] by increasing $\mathrm{Mg}$ supply to the roots has already been demonstrated (Löhnis, 1960; Elamin and Wilcox, 1985; Goss and Carvalho, 1992) but, to our knowledge, it was never shown before that this effect could at least partially be realized by $\mathrm{Mg}$ leaf-application. This finding is particularly interesting, since Mg deficiency often occurs on acid soils (Mengel and Kirkby, 2001), where an elevated risk of Mn toxicity exists due to reduction of $\mathrm{MnO}_{2}$ to $\mathrm{Mn}$, the plant-available form of this micronutrient. Consequently, $\mathrm{Mg}$ deficient plants growing in soil with low $\mathrm{pH}$ are especially prone to Mn toxicity. Lowering this risk by $\mathrm{Mg}$ addition to the soil has already been recommended (Löhnis, 1960) but leaf-application is much more favorable, since $\mathrm{Mg}$ is easily leached out in acid soils.

\section{CONCLUSION}

Magnesium deficiency severely compromises physiological efficiency of maize plants. Foliar fertilization of maize plants with 
$\mathrm{MgSO}_{4}$ turned to be an efficient means of $\mathrm{Mg}$ supply under severe $\mathrm{Mg}$ deficiency. Leaf-application of $\mathrm{Mg}$ proved to be as efficient as $\mathrm{Mg}$ resupply via the roots in ameliorating adverse effects of $\mathrm{Mg}$ deficiency, namely reduced photosynthetic capacity, high concentrations of other cations especially $\mathrm{Mn}$ in different plant tissues and reduced biomass. It might hence be of practical relevance to correct nutrient deficiencies during the growing season especially if $\mathrm{Mg}$ availability via root-uptake is limited due to poor soil properties or climatic conditions.

\section{ACKNOWLEDGMENT}

Mareike Jezek receives a grant from the Heinrich-Böll-Foundation, which is gratefully acknowledged.

\section{REFERENCES}

Balke, N. E., and Hodges, T. K. (1975). Plasma-membrane adenosine triphosphatase of oat roots - activation and inhibition by $\mathrm{Mg}^{2+}$ and ATP. Plant Physiol. 55, 83-86. doi: 10.1104/pp.55.1.83

Bergmann, W. (1983). Ernährungsstörungen bei Kulturpflanzen: Entstehung und Diagnose, 1st Edn. Jena: VEB Gustav Fischer Verlag.

Cai, J., Chen, L., Qu, H., Lian, J., Liu, W., Hu, Y., et al. (2012). Alteration of nutrient allocation and transporter genes expression in rice under $\mathrm{N}, \mathrm{P}, \mathrm{K}$, and Mg deficiencies. Acta Physiol. Plant. 34, 939-946. doi: 10.1007/s11738-011-0890-x

Cakmak, I. (2013). Magnesium in crop production, food quality and human health. Plant Soil 368, 1-4. doi: 10.1007/s11104-013-1781-2

Cakmak, I., Hengeler, C., and Marschner, H. (1994a). Changes in phloem export of sucrose in leaves in response to phosphorus, potassium and magnesium deficiency in bean plants. J. Exp. Bot. 45, 1251-1257. doi: 10.1093/jxb/45.9.1251

Cakmak, I., Hengeler, C., and Marschner, H. (1994b). Partitioning of shoot and root dry matter and carbohydrates in bean plants suffering from phosphorus, potassium and magnesium deficiency. J. Exp. Bot. 45, 1245-1250. doi: $10.1093 / \mathrm{jxb} / 45.9 .1245$

Cakmak, I., and Yazici, A. M. (2010). Magnesium: a forgotten element in crop production. Better Crops 94, 23-25.

Cao, W. X., and Tibbitts, T. W. (1992). Growth, carbon dioxide exchange and mineral accumulation in potatoes grown at different magnesium concentrations. J. Plant Nutr. 15, 1359-1371. doi: 10.1080/01904169209364403

Chatterjee, C., Nautiyal, N., and Agarwala, S. C. (1994). Influence of changes in manganese and magnesium supply on some aspects of wheat physiology. Soil Sci. Plant Nutr. 40, 191-197. doi: 10.1080/00380768.1994.10413293

Dordas, C. (2009). Foliar application of calcium and magnesium improves growth, yield, and essential oil yield of oregano (Origanum vulgare ssp hirtum). Ind. Crops Prod. 29, 599-608. doi: 10.1016/j.indcrop.2008.11.004

Elamin, O. M., and Wilcox, G. E. (1985). Effect of magnesium fertilization on yield and leaf composition of tomato plants. J. Plant Nutr. 8, 999-1012. doi: 10.1080/01904168509363402

Fernández, V., Sotiropoulos, V. T., and Brown, P. (2013). Foliar Fertilization - Scientific Principles and Field Practices, 1st Edn. Paris: International Fertilizer Industry Association (IFA).

Führs, H., Hartwig, M., Molina, L. E. B., Heintz, D., Van Dorsselaer, A., Braun, H.-P., et al. (2008). Early manganese-toxicity response in Vigna unguiculata L.- a proteomic and transcriptomic study. Proteomics 8, 149-159. doi: 10.1002/pmic. 200700478

Geilfus, C.-M., Zörb, C., Neuhaus, C., Hansen, T., Lüthen, H., and Mühling, K. H. (2011). Differential transcript expression of wall-loosening candidates in leaves of maize cultivars differing in salt resistance. J. Plant Growth Regul. 30, 387-395. doi: 10.1007/s00344-011-9201-4

Gerendás, J., and Führs, H. (2013). The significance of magnesium for crop quality. Plant Soil 368, 101-128. doi: 10.1007/s11104-012-1555-2

Gilliham, M., Athman, A., Tyerman, S. D., and Conn, S. J. (2011). Cell-specific compartmentation of mineral nutrients is an essential mechanism for optimal plant productivity-another role for TPC1? Plant Signal. Behav. 6, 1656-1661. doi: $10.4161 /$ psb.6.11.17797

Goss, M. J., and Carvalho, M. J. G. P. R. (1992). Manganese toxicity: the significance of magnesium for the sensitivity of wheat plants. Plant Soil 139, 91-98. doi: $10.1007 / \mathrm{BF} 00012846$
Gransee, A., and Führs, H. (2013). Magnesium mobility in soils as a challenge for soil and plant analysis, magnesium fertilization and root uptake under adverse growth conditions. Plant Soil 368, 5-21. doi: 10.1007/s11104-012-1567-y

Grzebisz, W. (2013). Crop response to magnesium fertilization as affected by nitrogen supply. Plant Soil 368, 23-39. doi: 10.1007/s11104-012-1574-Z

Guiet-Bara, A., Durlach, J., and Bara, M. (2007). Magnesium ions and ionic channels: activation, inhibition or block - a hypothesis. Magnes. Res. 20, 100-106.

Hermans, C., Vuylsteke, M., Coppens, F., Craciun, A., Inze, D., and Verbruggen, N. (2010a). Early transcriptomic changes induced by magnesium deficiency in Arabidopsis thaliana reveal the alteration of circadian clock gene expression in roots and the triggering of abscisic acid-responsive genes. New Phytol. 187, 119131. doi: 10.1111/j.1469-8137.2010.03258.x

Hermans, C., Vuylsteke, M., Coppens, F., Cristescu, S. M., Harren, F. J. M., Inze, D., et al. (2010b). Systems analysis of the responses to long-term magnesium deficiency and restoration in Arabidopsis thaliana. New Phytol. 187, 132-144. doi: 10.1111/j.1469-8137.2010.03257.x

Horst, W. J. (1983). Factors responsible for genotypic manganese tolerance in cowpea (Vigna unguiculata). Plant Soil 72, 213-218. doi: 10.1007/bf02181959

Kleiber, T., Golcz, A., and Krzesinski, W. (2012). Effect of magnesium nutrition on onion (Allium cepa L.). Part I. Yielding and nutrient status. Ecol. Chem. Eng. 19, 97-105. doi: 10.2478/v10216-011-0010-2

Kobayashi, N. I., Saito, T., Iwata, N., Ohmae, Y., Iwata, R., Tanoi, K., et al. (2012). Leaf senescence in rice due to magnesium deficiency mediated defect in transpiration rate before sugar accumulation and chlorosis. Physiol. Plant. doi: 10.1111/j.13993054.2012.12003.x [Epub ahead of print].

Kopittke, P. M., Lombi, E., McKenna, B. A., Wang, P., Donner, E., Webb, R. I., et al. (2013). Distribution and speciation of $\mathrm{Mn}$ in hydrated roots of cowpea at levels inhibiting root growth. Physiol. Plant. 147, 453-464. doi: 10.1111/j.13993054.2012.01674.x

Lin, D. C., and Nobel, P. S. (1971). Control of photosynthesis by $\mathrm{Mg}^{2+}$. Arch. Biochem. Biophys. 145, 622-632. doi: 10.1016/s0003-9861(71)80022-x

Löhnis, M. P. (1960). Effect of magnesium and calcium supply on the uptake of manganese by various crop plants. Plant Soil 12, 339-376. doi: 10.1007/BF02232990

Lynch, J. P., and St. Clair, S. B. (2004). Mineral stress: the missing link in understanding how global climate change will affect plants in real world soils. Field Crops Res. 90, 101-115. doi: 10.1016/j.fcr.2004.07.008

Maathuis, F. J. M. (2009). Physiological functions of mineral macronutrients. Curr. Opin. Plant Biol. 12, 250-258. doi: 10.1016/j.pbi.2009.04.003

Marschner, H. (2012). Marschner's Mineral Nutrition of Higher Plants, 3rd Edn. London: Academic Press.

Masuda, T. (2008). Recent overview of the Mg branch of the tetrapyrrole biosynthesis leading to chlorophylls. Photosyn. Res. 96, 121-143. doi: 10.1007/s11120008-9291-4

Mengel, K., and Kirkby, E. A. (2001). Principles of Plant Nutrition, 1st Edn. Dodrecht: Kluwer Academic Publishers. doi: 10.1007/978-94-010-1009-2

Millaleo, R., Reyes-Diaz, M., Alberdi, M., Ivanov, A. G., Krol, M., and Huner, N. P. A. (2013). Excess manganese differentially inhibits photosystem I versus II in Arabidopsis thaliana. J. Exp. Bot. 64, 343-354. doi: 10.1093/jxb/ers339

Morgan, M. A., and Jackson, W. A. (1976). Calcium and magnesium in ryegrass some differences in accumulation by roots in translocation to shoots. Plant Soil 44, 623-637. doi: 10.1007/bf00011381

Mou, D., Yao, Y., Yang, Y., Zhang, Y., Tian, C., and Achal, V. (2011). Plant high tolerance to excess manganese related with root growth, manganese distribution and antioxidative enzyme activity in three grape cultivars. Ecotoxicol. Environ. Saf. 74, 776-786. doi: 10.1016/j.ecoenv.2010.10.040

Neuhaus, C., Geilfus, C.-M., and Mühling, K.-H. (2014). Increasing root and leaf growth and yield in Mg-deficient faba beans (Vicia faba L.) by MgSO4 foliar fertilization. J. Plant Nutr. Soil Sci. 177, 741-747. doi: 10.1002/jpln.201300127

Neuhaus, C., Geilfus, C.-M., Zörb, C., and Mühling, K. H. (2013). Transcript expression of $\mathrm{Mg}$-chelatase and $\mathrm{H}+$-ATPase isogenes in Vicia faba leaves as influenced by root and foliar magnesium supply. Plant Soil 368, 41-50. doi: 10.1007/s11104-013-1711-3

Oikeh, S. O., Carsky, R., Kling, J. G., Chude, V. O., and Horst, W. J. (2003). Differential $\mathrm{N}$ uptake by maize cultivars and soil nitrate dynamics under $\mathrm{N}$ fertilization in West Africa. Agric. Ecosyst. Environ. 100, 181-191. doi: 10.1016/s0167-8809(03)00 194-4

Page, V., and Feller, U. (2005). Selective transport of zinc, manganese, nickel, cobalt and cadmium in the root system and transfer to the leaves in young wheat plants. Ann. Bot. 96, 425-434. doi: 10.1093/aob/mci189 
Pechanova, O., Takac, T., Samaj, J., and Pechan, T. (2013). Maize proteomics: an insight into the biology of an important cereal crop. Proteomics 13, 637-662. doi: 10.1002/pmic.201200275

Razinger, J., Dermastia, M., Koce, J. D., and Zrimec, A. (2008). Oxidative stress in duckweed (Lemna minor L.) caused by short-term cadmium exposure. Environ. Pollut. 153, 687-694. doi: 10.1016/j.envpol.2007.08.018

Reid, J. D., and Hunter, C. N. (2004). Magnesium-dependent ATPase activity and cooperativity of magnesium chelatase from Synechocystis sp PCC6803. J. Biol. Chem. 279, 26893-26899. doi: 10.1074/jbc.M400958200

Shabala, S., and Hariadi, Y. (2005). Effects of magnesium availability on the activity of plasma membrane ion transporters and light-induced responses from broad bean leaf mesophyll. Planta 221, 56-65. doi: 10.1007/s00425-004-1425-0

Steucek, G. L., and Koontz, H. V. (1970). Phloem mobility of magnesium. Plant Physiol. 46, 50-52. doi: 10.1104/pp.46.1.50

Stoyanova, Z., Poschenrieder, C., Tzvetkova, N., and Doncheva, S. (2009). Characterization of the tolerance to excess manganese in four maize varieties. Soil Sci. Plant Nutr. 55, 747-753. doi: 10.1111/j.1747-0765.2009.00416.x

Teklic, T., Vrataric, M., Sudaric, A., Kovacevic, V., Vukadinovic, V., and Bertic, B. (2009). Relationships among chloroplast pigments concentration and chlorophyllmeter readings in soybean under influence of foliar magnesium application. Commun. Soil Sci. Plant Anal. 40, 706-725. doi: 10.1080/00103620802 697939

Urrego-Pereira, Y. F., Martinez-Cob, A., Fernandez, V., and Cavero, J. (2013). Daytime sprinkler irrigation effects on net photosynthesis of maize and alfalfa. Agron. J. 105, 1515-1528. doi: 10.2134/agronj2013.0119

Verbruggen, N., and Hermans, C. (2013). Physiological and molecular responses to magnesium nutritional imbalance in plants. Plant Soil 368, 87-99. doi: $10.1007 /$ s11104-013-1589-0
Vrataric, M., Sudaric, A., Kovacevic, V., Duvnjak, T., Krizmanic, M., and Mijic, A. (2006). Response of soybean to foliar fertilization with magnesium sulfate (Epsom salt). Cereal Res. Commun. 34, 709-712. doi: 10.1556/crc.34.2006.1.177

White, P. J., and Broadley, M. R. (2009). Biofortification of crops with seven mineral elements often lacking in human diets - iron, zinc, copper, calcium, magnesium, selenium and iodine. New Phytol. 182, 49-84. doi: 10.1111/j.14698137.2008.02738.

Xing, W., Huang, W., and Liu, G. (2010). Effect of excess iron and copper on physiology of aquatic plant Spirodela polyrrhiza (L.) Schleid. Environ. Toxicol. 25, 103-112. doi: 10.1002/tox.20480

Conflict of Interest Statement: The authors declare that the research was conducted in the absence of any commercial or financial relationships that could be construed as a potential conflict of interest.

Received: 28 July 2014; accepted: 17 December 2014; published online: 09 January 2015.

Citation: Jezek M, Geilfus C-M, Bayer A and Mühling K-H (2015) Photosynthetic capacity, nutrient status, and growth of maize (Zea mays L.) upon MgSO4 leaf-application. Front. Plant Sci. 5:781. doi: 10.3389/fpls.2014.00781

This article was submitted to Crop Science and Horticulture, a section of the journal Frontiers in Plant Science.

Copyright (C) 2015 Jezek, Geilfus, Bayer and Mühling. This is an open-access article distributed under the terms of the Creative Commons Attribution License (CC BY). The use, distribution or reproduction in other forums is permitted, provided the original author(s) or licensor are credited and that the original publication in this journal is cited, in accordance with accepted academic practice. No use, distribution or reproduction is permitted which does not comply with these terms. 